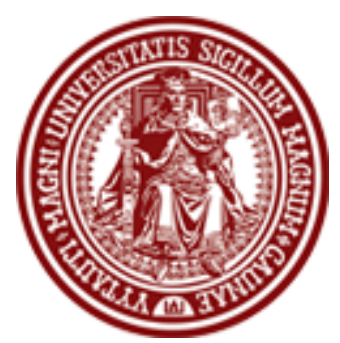

DE DE GRUYTER OPEN

\section{BALTIC JOURNAL OF LAW \& POLITICS}

A Journal of Vytautas Magnus University

VOLUME 10, NUMBER 2 (2017)

ISSN 2029-0454

\title{
'ACCESS TO JUSTICE' AND THE DEVELOPMENT OF THE VAN GEND EN LOOS DOCTRINE: THE ROLE OF COURTS AND OF THE INDIVIDUAL IN EU LAW
}

\author{
Nasiya Daminova \\ PhD Candidate in European Law \\ Scuola Superiore Sant'Anna (Italy) \\ Contact information \\ Address: Piazza Martiri della Libertà, 33, 56127 Pisa PI, Italy \\ Phone: +39050 883573 \\ E-mail address: n.daminova@santannapisa.it
}

Received: September 6, 2017; reviews: 2; accepted: December 14, 2017.

\section{ABSTRACT}

The 'access to justice' within the meaning of the Treaty of Lisbon and the pertinent CJEU jurisprudence is primarily seen as access to the EU judicial system, i.e. to the EU Member States' national courts applying the EU Law or/and the CJEU. The concept of 'access to justice' is therefore developing such premises of the Van Gend en Loos judgment as direct effect, vigilance of the EU individual, and the symbiotic relationship between the CJEU and national courts via the preliminary reference procedure. This work aims to explore the development of two basic ideas of Van Gend en Loos, i.e. granting directly enforceable EU rights to individuals and authorizing national courts to protect those rights, in light of the 'access to justice' concept within the meaning of the Lisbon Treaty - considering their importance for the realization of EU individuals' substantive rights and uncertainty surrounding this issue. The paper develops a critique of the theory of justice in EU Law, analyzing if and how the Van Gend en Loos premises influenced the role of individuals making an attempt to claim their EU rights and the 
role of the EU courts responsible for the enforcement of 'access to justice' in the European Union. The claim of this paper is that the new concept of 'access to justice' brought by the Lisbon Treaty may be seen as the further development of the Van Gend 'federalizing effect' for greater integration through law and an enhanced protection of the individual within the EU multilevel system of Human Rights protection.

\section{KEYWORDS}

Van Gend en Loos, access to justice, EU individual, preliminary reference procedure, European Convention on Human Rights, Charter of Fundamental Rights of the European Union 


\section{INTRODUCTION}

It is common knowledge that Van Gend en Loos is a key case for understanding European legal integration, because it manifested the central symbols and ideals of EU Law. The ideas of an autonomous legal order with more power than traditional treaties and the basic principle of the EU Law primacy over the national laws are the concepts which remain unchanged up to date. ${ }^{1}$ Such premises of great importance as (1) proclaiming of the individual as a European subject, alongside his or her national identity, and (2) constitution of the symbiotic relationship between the Court of Justice of the European Union (CJEU, EU Court of Justice) and domestic courts of the EU Member States, which defined a special importance of the preliminary reference procedure for the EU legal order, developed over time greatly and are now shaping the 'access to justice' concept created by the Treaty of Lisbon.

The Treaty of Lisbon is the first binding European Law which incorporates the formula of 'access to justice' via the provisions of the Treaty on European Union (TEU), the Treaty on the Functioning of the European Union (TFEU), and of the Charter of Fundamental Rights of the European Union (CFREU, EU Charter). Systematic analysis of two founding Treaties and pertinent CJEU case-law allows to state that the Treaty of Lisbon sees the 'access to justice' primarily as the access of the individuals or legal persons (Van Gend en Loos) to the EU judicial system. ${ }^{2}$ The Treaty drafters used such expressions as 'the Union shall facilitate access to justice... through the principle of mutual recognition of judicial and extrajudicial decisions' ${ }^{3}$ 'cross-border implications', ${ }^{4}$ 'addressed to the institutions and bodies of the Union... and to the Member States only when they are implementing Union law'. ${ }^{5}$ The approach chosen allows for the central adjudication of European Law through actions directly brought before the CJEU (Art. 19(1) TEU) and also provides for the decentralised adjudication of European Law in the national courts of the EU Member States.

In accordance with Art. 2 TEU, the 'rule of law and respect for human rights' are among the basic values of the Union. Art. 6 TEU proclaims that fundamental rights, as guaranteed by the European Convention on Human Rights (including Arts. 6 and 13 ECHR) shall constitute general principles of the Union's Law, and now

\footnotetext{
1 NV Algemene Transporten Expeditie Onderneming van Gend en Loos v Nederlandse Administratis der Belastingen, The Court of Justice of the European Union (1963, Case 26/62).

2 Elvira Méndez Pinedo, "Access to Justice as Hope in the Dark: In Search for a New Concept in European Law," International Journal of Humanities and Social Science No. 1 (2011): 9.

3 Consolidated version of the Treaty on the Functioning of the European Union, Official Journal of the European Union (2008, OJ C115/01), art. 67(4).

4 Ibid., art 81(1).

5 Charter of Fundamental Rights of the European Union, Official Journal of the European Union (2010, OJ C83/02), art. 51(1).
} 
considers the EU Charter provisions (including Art. 47 CFREU) a legally binding instrument of same legal value as the Treaties, which had a great influence on the post-Lisbon CJEU case-law development. The approach of the Treaty of Lisbon seems to be designed in accordance with the so-called third-wave 'access-to-justice approach,' which aims at coping with access barriers in a comprehensive manner and therefore shall lead to the increased level of interaction between the potential applicant(s) and the court(s) in question. ${ }^{6}$

Nevertheless, the development of these Van Gend premises through the lens of the Lisbon 'access to justice' concept has not been studied, although the CJEU and the European Court of Human Rights (ECtHR, Strasbourg Court) post-Lisbon practice in this area is quite extended. This work aims to explore the development of two basic ideas of Van Gend en Loos judgment, i.e. granting directly enforceable EU rights to individuals and authorizing national courts to protect those rights, in light of the 'access to justice' concept within the meaning of the Lisbon Treaty - considering their importance for realization of the EU individuals' substantive rights and uncertainty surrounding this issue. The paper develops a critique of the theory of justice in EU Law, analyzing if and how the Van Gend en Loos premises influenced the role of individuals making an attempt to claim their EU rights, and the role of the EU courts responsible for the enforcement of 'access to justice' in the European Union. The claim of this paper is that the new concept of 'access to justice' brought by the Lisbon Treaty may be seen as the further development of the Van Gend 'federalizing effect' for the greater integration through law and an enhanced protection of the individual within the EU multilevel system of Human Rights protection.

To illustrate these developments, firstly, an attempt is made to define the role of the individual seeking access to the EU judicial system in view of the CJEU'S Vereniging Milieudefensie ${ }^{7}$ and Inuit $^{8}$ lines of reasoning, as well as relevant ECtHR's judgments (Dhahbi ${ }^{9}$ and Schipani ${ }^{10}$ ). Secondly, this paper elaborates on the role of EU courts in realization of the 'access to justice' concept, considering the CJEU's Sánchez Morcillo ${ }^{11}$ and Opinion $2 / 13^{12}$ lines of reasoning in conjunction with the

\footnotetext{
${ }^{6}$ Bryant Garth and Mauro Cappelletti, "Access to Justice: The Newest Wave in the Worldwide Movement to Make Rights Effective," Buffalo Law Review No. 27 (1978): 223.

7 Council of the European Union and Others $v$ Vereniging Milieudefensie and Stichting Stop Luchtverontreiniging Utrecht, The Court of Justice of the European Union (2015, Joined Cases C-401/12 P and C-403/12 P).

8 Inuit Tapiriit Kanatami and Others $v$ Parliament and Council, The Court of Justice of the European Union (2011, Order in T-18/10); Inuit Tapiriit Kanatami and Others $v$ Commission, The Court of Justice of the European Union (2013, T-526/10); Inuit Tapiriit Kanatami and Others v Parliament and Council, The Court of Justice of the European Union (2013, C-583/11 P); Inuit Tapiriit Kanatami and Others $v$ European Commission, The Court of Justice of the European Union (2015, C-398/13 P).

9 Dhahbi v Italy, The European Court of Human Rights (2014, no. 17120/09).

10 Schipani and Others $v$ Italy, The European Court of Human Rights (2015, no. 38369/09).

11 Juan Carlos Sánchez Morcillo and María del Carmen Abril García v Banco Bilbao Vizcaya Argentaria SA, The Court of Justice of the European Union (2014, C-169/14).

12 Opinion 2/13, Accession of the European Union to the European Convention for the Protection of Human Rights and Fundamental Freedoms, The Court of Justice of the European Union (2014).
} 
relevant provisions of the Charter of Fundamental Rights of the European Union. Thus the first part of this paper is devoted to analyzing the role of the individual in EU Law in light of the Lisbon 'access to justice' concept. The second part discusses the role of the EU Member States' national courts and the Court of Justice of the European Union as actors providing access to the Union judicature, since the construct of Art. 19(1) TEU makes it clear that national judges are also the judges of Union Law. The concluding part presents the findings about the developments brought by the postLisbon case-law regarding actors responsible for legal enforcement of the 'access to justice'. The author does not claim to investigate the access to the broader notion of 'access to social justice' within the meaning of Arts 3, 6 TEU and the actors responsible for the distribution of social goods under the European Law, but rather to focus on the 'access to justice' as the possibility to approach the EU judicial system. ${ }^{13}$ The applications to the European Commission will not be discussed either, as these procedures are not (with rare exceptions) available for individuals aiming to invoke the EU Law provision in question.

1. 'ACCCESS TO JUSTICE' AND VAN GEND EN LOOS: THE ROLE OF THE INDIVIDUAL IN EU LAW

In Van Gend en Loos, the CJEU explicitly recognised the potential of an individual as a subject of the EU Law, although making the access to justice conditional upon 'direct effect' of the EU Law provisions in question, while also connecting the importance of cooperation between the individual and the EU legal system. ${ }^{14}$ This premise was developed after the Treaty of Lisbon adoption due to the new constructs of annulment proceedings (Art. 263 TFEU) and the defensive approach towards the preliminary rulings procedure (Art. 267 TFEU) as an individual Human Rights guarantee from the part of the ECtHR.

\subsection{LOCUS STANDI OF INDIVIDUALS FOR THE PURPOSES OF ART.} 263(4) TFEU

As a reaction to a wave of critique after the Courts' earlier judgments in the $U P A^{15}$ and Jego-Quere ${ }^{16}$ cases reaffirming the classic Plaumann test for 'individual

\footnotetext{
13 Hans Micklitz, "Social Justice and Access Justice in Private Law," European University Institute Working Paper LAW No. 2011/02 (2011) // http://ssrn.com/abstract=1824225.

14 The CJEU held: "[T]he Community constitutes a new legal order in international law, for whose benefit the States have limited their sovereign rights, albeit within limited fields, and the subjects of which comprise not only Member States but also their nationals. Community law, therefore, apart from legislation by the member States, not only imposes obligations on individuals but also confers on them legal rights." ${ }^{15}$ Unión de Pequeños Agricultores v Council, The Court of Justice of the European Union (2002, C-50/00 P).

${ }_{16}$ Jégo-Quéré v Commission, The Court of Justice of the European Union (2002, T-177/01).
} 
concern' precluding individuals from the usage of the annulment procedure, the TFEU created a potential for easier access to the EU legal system via the relaxation of the standing rules in relation to generally applicable Union acts. ${ }^{17}$ The text of Art. 263(4) TFEU directly enables '[a]ny natural or legal person', under the conditions laid down in the first and second paragraphs, to institute proceedings under the EU Law against an act addressed to that person or which is of direct and individual concern to them, and - in efforts to improve judicial protection for individuals - relaxes the standing requirements by removing the condition of individual concern for the category of regulatory acts which are of direct concern to such persons and do not entail implementing measures. ${ }^{18}$

The CJEU has recently made several important clarifications of these Treaty provisions, while giving interpretation to the notions of 'regulatory act' and an 'act which does not entail implementing measures' for the purposes of Art. 263(4) TFEU. In Inuit, ${ }^{19}$ the CJEU defined a 'regulatory act' as an act of general application adopted according to a procedure which is different from the legislative one (ordinary or special) as defined in Art. 289 TFEU. In T\&L Sugars, the EU Court of Justice espoused a broad interpretation of 'implementing measures', including any measure that at the European or national level gives effect or even only applies a regulatory act, irrespective of the existence of any discretion on their side to decide on the content of that measure. ${ }^{20}$ In almost all cases, the Court emphasized the rationale of Art. 263(4) TFEU - to give access to justice to individuals that otherwise would not have other alternatives than infringing the law. ${ }^{21}$

Nevertheless, in Inuit or T\&L Sugars the EU Court of Justice reasserted the Plaumann test, despite it having been criticised for being based on a formalistic rather than substantial element. ${ }^{22}$ Although in Inuit the CJEU agreed that the conditions of admissibility laid down in the fourth paragraph of Art. 263 TFEU must be interpreted in view of the right to effective judicial protection proclaimed by Art. 47 of the Charter, the Court emphasized that such an interpretation cannot have the effect of setting aside the conditions expressly laid down in the Treaty. ${ }^{23}$ Inuit is also important since it proclaimed that '...it is therefore for the Member States to establish a system of legal remedies and procedures which ensure respect for the fundamental

\footnotetext{
17 Plaumann $v$ Commission, The Court of Justice of the European Union (1963, Case 25/62).

18 Koen Lenaerts, Ignace Maselis, and Kathleen Gutman, EU Procedural law (Oxford: Oxford University Press, 2015), 254.

19 Inuit Tapiriit (C-583/11 P), supra note 8, para. 61.

$20 T$ \& L Sugars Ltd and Sidul Açúcares, Unipessoal Lda v European Commission, The Court of Justice of the European Union (2013, T-279/11), para. 37.

${ }^{21}$ Inuit Tapiriit (T-18/10), supra note 8, para. 50; Telefónica SA v European Commission, The Court of Justice of the European Union (2013, C-274/12 P), para. 27.

22 Roberto Mastroianni and Andrea Pezza, "Access of Individuals to the European Court of Justice of the European Union Under the New Text of Article 263, Para.4, TFEU," Rivista italiana di diritto pubblico communitario No. 5 (2014): 930.

${ }^{23}$ Inuit Tapiriit (C-583/11 P), supra note 8, para.35.
} 
right to effective judicial protection'. ${ }^{24}$ In the context of Art. 263(4) TFEU it may be seen as an intention of the Union to reduce the CJEU intervention and to shift the responsibility for EU Law enforcement to the Member States' courts so as to avoid overburdening the CJEU with the individual complaints.

It will be argued that this approach to the individual locus standi is not likely to change taking into account recent Vereniging Milieudefensie and Stichting Natuur judgments. In both of these cases, elaborating on the access of NGOs to the CJEU in the light of Art. 9(3) of the Aarhus Convention, the EU Court of Justice dismissed the applications for annulment without referring the cases back to the General Court. An important aspect of the legal reasoning was that the annulment procedure in relation to the Regulation No. $1367 / 2006$ 'concerns only one of the remedies available to individuals for ensuring compliance with EU environmental law', and recalled that Art. 9(3) of the Aarhus Convention leaves leeway and discretion to the Contracting Parties when defining the rules for the implementation of administrative or judicial procedures in the context of environmental cases. Considering earlier CJEU statement in Lesoochranárske zoskupenie about the potential applicability of Aarhus convention on the national level, it may be seen as a strong message to the national courts to relinquish their well-vested traditional approaches to standing for environmental NGOs to prevent parties from an application of Art. 263(4) TFEU in environmental matters. ${ }^{25}$ Since Art. 9(3) of the Aarhus Convention may also be applicable to the individual applicants ('members of the public'), it is quite probable that the EU Court of Justice might follow the similar path in further cases related to admissibility of individual applications for annulment.

An additional argument in this regard may be the Strasbourg system view on individual locus standi expressed in the Bosphorus case. ${ }^{26}$ The ECtHR recognised the limited standing for individuals under Art. 263(4) TFEU but accepted the alternative means of redress in actions for damages and the preliminary ruling procedure as sufficiently protecting their rights. It referred to the whole system of review in the EU as guaranteeing the compliance with Union rules, thus also the control exercised by actions brought by Member States and Institutions of the Union. ${ }^{27}$ Consequently, the restriction on locus standi in Art. 263(4) TFEU was not in itself found to be in breach of the ECHR, but a rebuttal of the presumption could be possible if the protection would be deemed as 'manifestly deficient', which was not the case in

\footnotetext{
24 Ibid., paras. 98 and 100.

25 Lesoochranárske zoskupenie VLK v Ministerstvo životného prostredia Slovenskej republiky, The Court of Justice of the European Union (2011, C-240/09), para. 46.

26 Bosphorus Hava Yollari Turizm Ve Ticaret Anonim Sirketi v Ireland, The European Court of Human Rights (2005, no. 45036/98).

27 Ibid., paras. 162-164.
} 
Bosphorus. ${ }^{28}$ These lines of legal reasoning make clear that the EU Court of Justice is now unwilling to reconsider its well-entrenched Plaumann-doctrine for direct actions, while the case law on individual access to justice at national level looks seemingly progressive and makes an emphasis on the duty of consistent interpretation that is resting upon the national courts in this respect.

\subsection{LOCUS STANDI OF INDIVIDUALS FOR THE PURPOSES OF ART. 267} TFEU

Art. 267 TFEU concerns either 'any court or tribunal of a Member State' ('may') or the court or tribunal of a Member State against whose decisions there is no judicial remedy under national law ('shall') which request the EU Court of Justice to give a ruling concerning (a) the interpretation of the Treaties or (b) the validity and interpretation of acts of the institutions, bodies, offices or agencies of the Union. The Treaty of Lisbon has not directly defined an individual participating in the national procedure as a subject enabled to invoke the procedure, since the right and the duty to submit a reference have been vested in the national courts - not only to enable them to make sure that the individual's EU Law rights are respected, but also more generally to ensure the uniform and correct application of the EU Law in all Member States.

However, preliminary rulings procedure has historically been an important route of access to the CJEU from the part of individuals since it is the initiative of the party of the case which often instigates a judge to request a preliminary ruling. ${ }^{29}$ The need for this cooperation between the individual, national court and the EU Court of Justice arises from two limitations of the Union system, i.e. the lack of standing for individuals to bring appeals from national judicial decisions or bring an action for annulment to the EU Court of Justice on the one hand, and the CJEU's lack of coercive powers to enforce its judgments on the other - which makes the preliminary rulings procedure the only (indirect) way for individuals to challenge national law inconsistent with the EU Law provisions. ${ }^{30}$

Again, it is still within the discretion of the Member States to enable a party of the case to invoke a preliminary ruling mechanism. For example, in Germany the judge's refusal to submit a request to the CJEU may be considered a breach of the constitutional right to 'a lawful judge' under Art. 101(1) of the German Basic Law

\footnotetext{
28 Ibid., para. 166.

29 Morten Broberg, "Judicial Coherence and the Preliminary Reference Procedure: Article 267 TFEU as a Private Party Remedy for ensuring Judicial Coherence in Europe," Review of European Administrative Law No. 8 (2015): 10-11.

30 Marcus Klamert, The Principle of Loyalty in EU Law (Oxford: Oxford University Press, 2014 ), 14.
} 
(Grundgesetz), if such a refusal is considered to be arbitrary and non-justifiable. ${ }^{31}$ Another factor which may enable a private party to instigate a preliminary rulings procedure is the Member State's legal culture. In those legal systems where the role of legal counsel in clarifying the case is considerable, such as Great Britain, Ireland, and Denmark, references for preliminary rulings are generally made at the initiative of the parties. This has even led some to argue that, in the UK at least, the reality behind the preliminary procedure even before the Lisbon was already closer to a litigant - EU Court of Justice relationship (with the national court acting as a relay between the two) than a national court - EU Court of Justice dialogue as frequently proclaimed by the CJEU. ${ }^{32}$

The CJEU post-Lisbon jurisprudence also emphasizes the role of preliminary rulings procedure for the protection of the individual's EU rights. In Inuit and Telefónica, the EU Court of Justice encourages private parties to plead the invalidity of the basic act at issue before the national courts and tribunals and causes the latter to request a preliminary ruling from the EU Court of Justice, pursuant to Art. 267 TFEU, when the implementation of the 'regulatory act which entails implementing measures' is a matter for the Member States. ${ }^{33}$ Since these statements are made in the context of discussion on the individual locus standi for the purposes of Art. 263(4) TFEU, the CJEU seems to recognise a preliminary rulings procedure as a way of challenging of European Law alternative to the individual action of annulment.

The recent developments in the ECtHR case-law interpreting the position of the EU individual in preliminary rulings procedure in the light of Art. $6 \mathrm{ECHR}$ ('the right to a fair trial') also present a special interest for the present research. In some way, the ECtHR was forced to touch upon the question of EU Law in cases concerning the failure of the national court to make a preliminary reference to the CJEU, finding this under certain circumstances to constitute a violation of Art. 6(2) ECHR. In Dhahbi v. Italy, the ECtHR stated that a refusal by a national court of last instance (Corte de Cassazione) to make a reference to the EU Court of Justice, providing no reasoning at all when justifying its decision, entails a breach of Art. 6 ECHR. When the 'court or tribunal of a Member State against whose decisions there is no judicial remedy under national law' refuses to make use of Art. 267 TFEU providing no legal reasoning, despite the fact that the appellant has raised it in the appeal, such refusal would be in breach of Art. 6 ECHR. ${ }^{34}$ This line of reasoning is supported by Schipani vs. Italy, where the submissions of the parties supporting the necessity to submit a preliminary

\footnotetext{
${ }^{31}$ Beschluss der 3, Bundesverfassungsgericht, Kammer des Zweiten Senats, The Federal Constitutional Court of the Federal Republic of Germany, 2014, 2 BvR 1549/07.

32 Morten Broberg, Preliminary References to the European Court of Justice (Oxford: Oxford University Press, 2014), 281.

33 Inuit Tapiriit (C-583/11 P), supra note 8, para. 93; Telefónica SA, supra note 21, para. 29.

34 Dhahbi, supra note 9, paras. 33-34.
} 
reference were disregarded by the same court in question; the only aspect which was considered was whether the issue was an acte clair or an acte éclairé. According to the ECtHR, it was therefore not clear from the reasoning of the judgment whether that question was considered irrelevant, related to a provision which was clear or had already been interpreted by the CJEU, or whether it was simply ignored; it therefore came to the conclusion that there had been a breach of Art. 6 ECHR. ${ }^{35}$

Although these outcomes may be seen as an intervention by the ECtHR in EU Law's most sensitive area, the Strasbourg Court emphasises the individual litigant's benefits stemming from the guarantee of Art. 6(1) of the Convention. The ECtHR stated that providing no justification for the refusal would amount to denying the individual's right, '...in the determination of his civil rights and obligations (...) to a fair and public hearing (...) by an independent and impartial tribunal (...)'. In this specific case, the court's statement may be seen as a proposal to the CJEU to consider Art. 6(1) of the European Convention as a relevant basis for a EU Law individual to invoke a preliminary reference mechanism in the procedure before the Member State national court or tribunal.

\section{2. 'ACCESS TO JUSTICE' AND VAN GEND EN LOOS: THE ROLE OF THE EUROPEAN UNION COURTS}

The judgment, through the direct effect doctrine, created a two-level system of EU Law adjudication: the CJEU and the Member States courts, acting as an integral part of the EU legal system (Foto-Frost). ${ }^{36}$ In Van Gend, the EU Court of Justice was concerned that a different outcome 'would remove all direct legal protection' of the individual rights of the Community's nationals: '[t]here is the risk that recourse to the procedure under these Articles would be ineffective if it were to occur after the implementation of a national decision taken contrary to the provisions of the Treaty'. ${ }^{37}$

This multilevel system of protection was driven by the implicit idea that the individual and his/her rights enjoy better protection if an 'external' judicial control complements 'internal', domestic, judicial remedies. Kilpatrick explains these routes as the 'by-products of the 'great leap' taken by the EU Court of Justice:

'The twin doctrines of direct effect and supremacy to ensure that private individuals... would provide both more and better compliance by Member States with EU Law obligations they had assumed ... The Court of Justice set out a division

\footnotetext{
35 Schipani, supra note 10 , paras. 71-73.

36 Foto-Frost v Hauptzollamt Lübeck-Ost, The Court of Justice of the European Union (1987, Case 314/85).

37 Eyal Benvenisti and George Downs, "The Premises, Assumptions, and Implications of Van Gend en Loos: Viewed from the Perspectives of Democracy and Legitimacy of International Institutions," European Journal of International Law No. 25 (2014): 86.
} 
of remedial competences which recognised the inevitable reliance of the Union legal order and the Court of Justice on national courts and remedies in the private enforcement model. Rights or substantive issues concerning EU Law were for the Court of Justice while remedies and procedural issues concerning the enforcement of EU Law rights were for the national legal orders and the national courts'. ${ }^{38}$

The TEU confirms this viewpoint and uses an innovative reference of 'remedies' in the text of Art. 19(1) TEU: this provision recalls that it is for the Member States' courts - and therefore not in principle for the EU - to provide 'remedies sufficient to ensure effective legal protection in the fields covered by Union law', which formalises the model of decentralised judicial review chosen by the Union. This approach was further developed through the Lisbon Treaty provisions, and now the institutions responsible for the legal enforcement of the 'access to justice' concept shall therefore be divided in two large groups: (a) the national courts and tribunals of the Member States (Art. 19(1) TEU, Rewe-Comet) ${ }^{39}$ and (b) the CJEU. The post-Lisbon case law demonstrates that the role of both groups has become even more significant.

\section{1. 'ACCESS TO JUSTICE': THE ROLE OF NATIONAL COURTS AND TRIBUNALS OF THE EU MEMBER STATES}

It will be argued that the role of the EU Member States' national courts in relation to the 'access to justice' concept should be seen through the lens of the loyalty principle codified by the Treaty of Lisbon. Supranational loyalty enshrined by Art. 4(3) TEU looks to national federal systems for solutions in defining the cooperation duties of federative entities vis-à-vis the federal State; in this sense, EU loyalty can be considered an expression of federal loyalty, under which 'each level and unit of government must act to ensure the proper functioning of the system of governance as a whole'. ${ }^{40}$ The role of the national courts in the area of 'access to justice' may therefore be seen in two dimensions: the duty of consistent interpretation established by Von Colson and Marleasing (guaranteed by the principles of sincere cooperation and loyalty after the Treaty of Lisbon $)^{41}$ and the new legal construct of a right (Art. 267(2) or a duty (Art. 267 (3) TFEU to submit a request for preliminary ruling to the EU Court of Justice).

\footnotetext{
38 Claire Kilpatrick, Tonia Novitz, and Paul Skidmore, The Future of Remedies in Europe (London: Bloomsbury Publishing, 2000), 2-3.

${ }^{39}$ Rewe $v$ Landwirtschaftskammer fuer das Saarland, The Court of Justice of the European Union (1976, Case 33/76); Comet v Produktschap voor Siergewassen, The Court of Justice of the European Union (1976, Case 45/76).

40 Daniel Halberstam, "Of Power and Responsibility: The Political Morality of Federal Systems," Virginia Law Review No. 90 (2004): 734.

${ }^{41}$ Consolidated version of the Treaty on the European Union, Official Journal of the European Union, 2008, OJ C115, art. 4(3).
} 
The duty of consistent interpretation is based on the principle of direct effect, and is a natural consequence for the functioning of a decentralised system such as the EU legal order. According to the Rewe-Comet formula, national courts are entrusted with ensuring the legal protection which individuals derive from the direct effect of the Union law, applying the principle of sincere cooperation laid down by Art. 4(3) TEU. ${ }^{42}$ Therefore, the role of national courts as the EU courts when adjudicating in an EU matter may be seen in two dimensions: for the individual and the national court itself - ensuring the protection of rights granted under EU Law; for the EU - ensuring the effectiveness of EU Law.

It could be said that the duty of consistent interpretation after the Lisbon Treaty is closely connected with the principle of effective judicial protection stemming from Art. 47 of the Charter of Fundamental Rights of the EU. The obligations of the Member States under Arts. 4(3) and 19 TEU are thus mirrored by the individual right to effective judicial review. This means that much of the case-law on Art. 47 concerns the rights on access to national courts and the remedies available before such courts in cases when the EU Law element is present. ${ }^{43}$ These provisions codify such preLisbon case-law as the Unibet case, where the national court was required to interpret the rules governing its own jurisdiction 'in such a way as to enable those rules, wherever possible, to be implemented in such a manner as to contribute to the attainment of the objective... of ensuring effective judicial protection of an individual's rights under Community law. ${ }^{\prime 44}$ The Unibet judgment shows that a broader principle of effective judicial protection 'imposes on national courts a duty of consistent interpretation reminiscent of that laid down in Marleasing. ${ }^{145}$

In recent judgments, this tendency is becoming more and more evident. For example, the EU Court of Justice tested the respect of both the limits of loyalty and of the principle of effective judicial protection in Alassini. While founding, in principle, no violation of the principles of equivalence and effectiveness, provided that certain conditions were respected, the Court conversely recognised the existence of a restriction to the principle of effective judicial protection, maintaining that national legislation introduced an additional step for access to the courts which might prejudice judicial protection of the individuals. Such a restriction was nevertheless found admissible in light of the principles of necessity and proportionality. ${ }^{46}$ In

\footnotetext{
42 Rewe, supra note 39, para. 5; Comet, supra note 39, para. 12.

43 Charter of Fundamental Rights of the European Union, supra note 5, art. 51.

44 Unibet (London) Ltd and Unibet (International) Ltd $v$ Justitiekanslern, The Court of Justice of the European Union (2007, C-432/05), para. 44.

45 Marleasing SA $v$ La Comercial Internacional de Alimentacion SA, The Court of Justice of the European Union (1990, C-106/89); Anthony Arnull, "The Principle of Effective Judicial Protection in EU Law: An Unruly Horse?" European Law Review No. 36 (2011): 55.

46 Alassini and Others, The Court of Justice of the European Union (2010, Joined Cases C-317/08 to C320/08), paras. 47, 50-60.
} 
Sánchez Morcillo, the CJEU stressed that, as regards the duty of consistent interpretation and the principle of effectiveness, the Court held that a requirement of judicial protection, guaranteed by Art. 47 of the Charter, is binding on the national court. ${ }^{47}$ In Orizzonte Salute, the CJEU emphasized the interpretation of Directive $89 / 665$ in the light of the fundamental rights set out in the Charter, in particular the right to an effective remedy before a court or tribunal, laid down in Art. 47 thereof. ${ }^{48}$ This approach seems to be in line with the intentions of the Lisbon Treaty drafters who intended, with Art. 19(1) TEU, to strengthen individual legal protection in the fields covered by Union law before national courts - which defines an increasing importance and, in some way, widens the discretion of the national courts in enforcing the 'access to justice' concept. ${ }^{49}$

Cooperation of the national courts and the CJEU in the form of preliminary references may also be seen as a realisation of the principle of sincere (loyal) cooperation under Art. 4(3) TEU; from this point of view, Art. 19(1) TEU and 267 TFEU may be seen as lex specialis to Art. 4(3) TEU and a manifestation of Lisbon adherence to the principles of cooperative federalism, even in relation to the 'access to justice' concept. Recent CJEU practice demonstrates quite a defensive approach to the right (or duty) of the national courts to submit preliminary references to the CJEU, making the preliminary rulings procedure a crucial element of the 'complete system of legal remedies and procedures designed to ensure review of the EU acts'. ${ }^{50}$

In the Melki and Abdeli cases, the EU Court of Justice stated that national courts cannot be prevented from referring questions to the CJEU, and therefore, if an interlocutory procedure giving priority to the review of constitutionality of national law effectively prevents these courts from referring questions to the CJEU, such a procedure shall be prohibited under Art. 267 TFEU. ${ }^{51}$ The EU Court of Justice emphasised the special importance of Art. 267 TFEU, stating that the national courts shall remain free to submit a reference for a preliminary ruling to the CJEU at whatever stage of proceedings they consider appropriate, on any question they consider necessary. ${ }^{52}$ In the groundbreaking Opinion 2/13, the EU Court of Justice goes even further, describing the preliminary reference procedure as 'the keystone of the judicial system established by the Treaties', which will be affected if no special provisions are made to balance the relationship between optional Protocol 16 ECHR

\footnotetext{
47 Sánchez Morcillo, supra note 11, para. 35.

48 Orizzonte Salute - Studio Infermieristico Associato v Azienda Pubblica di Servizi alla persona San Valentino - Città di Levico Terme and Others, The Court of Justice of the European Union (2015, C-61/14), para. 49.

${ }^{49}$ Inuit Tapiriit (C-583/11 P), supra note 8, paras. 34-35, 93-96, 100-104.

50 Ibid., para. 92.

51 Aziz Melki and Sélim Abdeli, The Court of Justice of the European Union (2010, Joined Cases C-188/10 and C-189/10), para. 57.

52 Ibid., para. 57.
} 
and the preliminary ruling procedure of Art. 267 TFEU, as it will influence the autonomy and effectiveness of the latter procedure. ${ }^{53}$

In Ferreira da Silva, the CJEU again emphasised the duty of a national court or tribunal, against whose decisions there is no judicial remedy under national law, to comply with its obligation to make a reference to the Court in order to avert the risk of an incorrect interpretation of EU law, considering its crucial importance for judicial coherence and overcoming divergences in judicial decisions within the European Union. ${ }^{54}$ Moreover, the EU Court of Justice clarified in recent Global Starnet Ltd judgment that Art. 267(3) TFEU must be interpreted as meaning that a national court against whose decisions there is no judicial remedy is required, in principle, to refer a question for a preliminary ruling concerning the interpretation of European Law even if, in the course of the same national proceedings, the constitutional court of the EU Member State concerned has assessed the constitutionality of national rules in the light of regulatory parameters with content similar to rules under EU Law. ${ }^{55}$ These lines of reasoning demonstrate that the CJEU continues to encourage the EU Member States' courts, especially the courts or tribunals against whose decisions there is no judicial remedy under national law, to invoke the preliminary rulings mechanism, even in case of small doubts, therefore shifting responsibility for EU Law enforcement from the EU Court of Justice to the courts in the Member States.

\section{2. 'ACCESS TO JUSTICE': THE ROLE OF THE COURT OF JUSTICE OF THE} EUROPEAN UNION

In accordance with Art. 19(1) TEU, the EU Court of Justice remains the highest court of the legal order which has the task of adjudication on the validity of norms by reference to the Treaties, and its jurisdiction is exclusive as no other court has the competence to annul EU legislation. The Court is expressly granted jurisdiction to assess the legality of union acts and can exercise both ultra vires and fundamental rights review. This entails CJEU jurisdiction for both inter-institutional and Union/Member States conflicts of competence, i.e. jurisdiction which corresponds to essential functions of a typical federal state constitutional court. ${ }^{56}$ These features define exclusive position of the EU Court of Justice as an actor shaping the concept of 'access to justice' within the meaning of the Lisbon Treaty. The key instrument in this regard is the Charter of Fundamental Rights of the European Union which has

\footnotetext{
53 Opinion 2/13, supra note 12 , paras. 197-199.

54 João Filipe Ferreira da Silva e Brito and Others v Estado português, The Court of Justice of the European Union (2015, C-160/14), paras. 43-44.

55 Global Starnet Ltd v Ministero dell'Economia e delle Finanze and Amministrazione Autonoma Monopoli

di Stato, The Court of Justice of the European Union (2017, C-322/16), paras. 24-26.

56 Kaarlo Tuori, European Constitutionalism (Cambridge: Cambridge University Press, 2015), 50.
} 
the same legal value as the Treaties. ${ }^{57}$ After the Treaty of Lisbon, the Charter obtained a prominent position in the EU legal system and its application has become a matter of daily business. ${ }^{58}$

For example, in ZZ $v U K$ Home Secretary, whilst deciding a case concerning the implementation of Directive 2004/38 on the freedom of movement which does not harmonise the national rules of procedure in case of refusal, the CJEU considered that national remedies must afford effective judicial protection as set out in Art. 47 of the EU Charter and that the basis for a refusal must be disclosed to the person concerned. ${ }^{59}$ The case of $D E B$ (although not directly related to individual persons) involved such an expansion of the right of effective judicial protection. After having engaged in a thorough analysis of the ECtHR case law, the CJEU eventually relied mainly on Art. 47 CFREU to expand the right to legal aid to legal persons and not only to natural persons, thus reaching an outcome that did not clearly emerge from the ECtHR jurisprudence. ${ }^{60}$ In the N.S. case, the Court held that Member States are prohibited from transferring an asylum seeker in accordance with the Dublin II Regulation, if there are substantial grounds for believing that the asylum seeker would face a real risk of being subjected to inhuman or degrading treatment within the meaning of Art. 3 ECHR and Art. 4 CFREU, also considering the guarantees enshrined in Art. 47 of the EU Charter. Since the CJEU followed the approach earlier taken by the ECtHR in M.S.S. $v$ Greece and Belgium, the N.S. judgment has opened the floor for questions concerning the application of higher CFREU standards of protection than those guaranteed by the corresponding ECHR provisions in individual cases, therefore adding an additional argument to the discussion.

The CJEU approach taken in the Chalkor case might present special interest as the CJEU noted that since Art. 47 of the EU Charter implements in EU Law the protection afforded by Art. 6(1) ECHR, it was necessary to refer only to Art. 47 CFREU. ${ }^{61}$ The Explanations relating to the Charter of Fundamental Rights of the European Union emphasize that Art. 47 CFREU is primarily based on the rights enshrined in Arts. 13 and 6(1) ECHR, and therefore the meaning and scope of these rights shall be the same as laid down by the Convention. ${ }^{62}$ In line with Opinion 2/13, where the CJEU applied the principle of absolute primacy to the CFREU, it may be seen as a claim for the development of independent body of the CJEU case-law

57 Consolidated version of the Treaty on the European Union, supra note 41, art. 6(1).

58 George Arestis, "Fundamental rights in the EU: three years after Lisbon, the Luxembourg perspective," Research Paper in Law No. 2/2013 (2012) // http://aei.pitt.edu/43293/.

${ }^{59}$ ZZ v Secretary of State for the Home Department, The Court of Justice of the European Union (2013, C-300/11).

${ }^{60}$ Deutsche Energiehandels- und Beratungsgesellschaft $\mathrm{mbH} v$ Bundesrepublik Deutschland, The Court of Justice of the European Union (2010, C-279/09).

61 Chalkor v. Commission, The Court of Justice of the European Union (2011, C-386/10 P), para. 51.

62 Explanations relating to the Charter of Fundamental Rights, Official Journal of the European Union (2007, OJ C303/02). 
favoring more extensive protection within the fields covered by the EU Law. Considering the extension of the CJEU jurisdiction to the police and judicial cooperation in criminal matters ${ }^{63}$ and to the policies related to free movement of persons ${ }^{64}$ (in particular, judicial cooperation in civil matters, recognition and enforcement of judgments), one may expect further developments in these areas based on Art. 52(3) of the Charter of Fundamental Rights of the European Union, which will further develop the concept of 'access to justice' in European Law.

\section{CONCLUSIONS}

This article sheds light on development of the Van Gend en Loos premises within the framework of 'access to justice' concept framed by the Treaty of Lisbon, i.e. enabling individuals to evoke their EU rights before the EU courts and the duty of the EU courts to apply EU Law to the disputes before them, therefore providing private parties with access to the said substantive rights. The author analyzed the present role of the individual, making an attempt to access the EU judicial system in the light of the Vereniging Milieudefensie, Inuit and Dhahbi lines of reasoning, then tried to focus on the role of the EU courts for the realization of the 'access to justice' in the light of the Sánchez Morcillo and Opinion 2/13 lines of reasoning in conjunction with Art. 47 of the Charter of Fundamental Rights of the European Union. The main argument presented was that the 'access to justice' concept reflects the federalist approach of the Treaty of Lisbon aiming both at the better legal protection of EU individuals and the coherent cooperation within multilevel judicial system of the European Union. There are several crucial points which are worthy of mention.

Firstly, the analysis of recent practice demonstrates the CJEU's awareness of the individual access to justice and adherence to coherent cooperation between different levels of the EU legal system - which may be seen as a reflection of the 'federalist' spirit of the Lisbon Treaty. The main purpose of the 'access to justice' formula has been not only to improve the position of the individual due to the duty to follow the ECHR standards of protection (Arts. 6, 13 of the Convention) and binding force of the CFREU provisions (Art. 47 of the EU Charter), but to guarantee effective application of the EU Law at the EU and Member States' levels. One could say that the national courts and the EU Court of Justice work together enforcing the 'access to justice' in EU Law, being complementary parts in a shared legal sphere, instead of

63 Formerly Title VI of the EU Treaty.

64 Formerly Title IV of the EC Treaty. 
operating independently in separate spheres - which illustrates the EU legal order shift to 'cooperative federalism' model. ${ }^{65}$

Secondly, it is possible to claim that the role of the EU individual as an actor enabled to gain access to the EU judicial system has significantly increased due to the Lisbon legal novelties and pertinent CJEU and ECtHR jurisprudence. Although the Plaumann test restricting locus standi for the purposes of Art. 263(4) TFEU is not likely to be reconsidered, the Inuit and Telefónica lines of reasoning seem to encourage private parties to challenge the EU Law before the national courts and tribunals and cause the latter to request a preliminary ruling from the EU Court of Justice, at least when the case concerns the act entails implementing measures from the part of the EU Member States. This viewpoint may also be supported by the Strasbourg Dhahbi and Schipani judgments which demonstrate that Art. 6(1) of the European Convention might be considered a relevant basis for the EU individual to invoke a preliminary reference mechanism, at least in the procedure before the EU Member State court or tribunal against whose decisions there is no judicial remedy under national law.

Thirdly, the 'access to justice' concept framed by the Lisbon Treaty changes the roles of the EU courts sufficiently. The Alassini line of reasoning demonstrates that the principle of loyalty enshrined in Art. 4(3) TEU is becoming more and more important for the enforcement of EU rights by the Member States' courts, since this duty of the national courts is scrutinised in the light of the effective judicial protection principle codified by Art. 47 of the EU Charter provisions. This emphasis on national remedies may be seen as the shift in the attribution of responsibility for enforcement of EU Law to the Member States level, reducing the necessity of the EU Court of Justice intervention and enabling the issues of EU Law to be resolved closer to the citizens. At the same time, the Melki approach demonstrates the crucial role of the national courts as the key elements of preliminary rulings system set up by Art. 267 TFEU, as part of which the former are closely involved in the correct application and uniform interpretation of European Union Law and also in the protection of individual rights conferred by that legal order. The CJEU becomes an actor shaping the concept of 'access to justice' as such, and even the interventions of the Strasbourg system of Human Rights protection do not seem possible in light of the Opinion 2/13 defensive approach to the EU Charter primacy. Art. 47 CFREU is of special importance in this regard since it may serve as a legal basis for formation of the body of the CJEU case-law, favouring more extensive protection in comparison

65 Robert Schütze, From Dual to Cooperative Federalism: The Changing Structure of European Law (Oxford: Oxford University Press, 2009), 6-7. 
with the ECHR level in accordance with Art. 52(3) of the Charter of Fundamental Rights of the European Union.

\section{BIBLIOGRAPHY}

1. Arestis, George. "Fundamental rights in the EU: three years after Lisbon, the Luxembourg perspective." Research Paper in Law No. 2/2013 (2012): 1-13 // http://aei.pitt.edu/43293/.

2. Arnull, Anthony. "The Principle of Effective Judicial Protection in EU Law: An Unruly Horse?" European Law Review No. 36 (2011): 51-70.

3. Benvenisti, Eyal, and George Downs. "The Premises, Assumptions, and Implications of Van Gend en Loos: Viewed from the Perspectives of Democracy and Legitimacy of International Institutions." European Journal of International Law No. 25 (2014): 85-102.

4. Broberg, Morten. "Judicial Coherence and the Preliminary Reference Procedure: Article 267 TFEU as a Private Party Remedy for ensuring Judicial Coherence in Europe." Review of European Administrative Law No. 8 (2015): 9-37.

5. Broberg, Morten. Preliminary References to the European Court of Justice. Oxford: Oxford University Press, 2014.

6. Garth, Bryant, and Mauro Cappelletti. "Access to Justice: The Newest Wave in the Worldwide Movement to Make Rights Effective." Buffalo Law Review No. 27 (1978): 181-292.

7. Halberstam, Daniel. "Of Power and Responsibility: The Political Morality of Federal Systems." Virginia Law Review No. 90 (2004): 732-834.

8. Kilpatrick, Claire, Tonia Novitz, and Paul Skidmore. The Future of Remedies in Europe. London: Bloomsbury Publishing, 2000.

9. Klamert, Marcus. The Principle of Loyalty in EU Law. Oxford: Oxford University Press, 2014.

10. Lenaerts, Koen, Ignace Maselis, and Kathleen Gutman. EU Procedural law. Oxford: Oxford University Press, 2015.

11. Mastroianni, Roberto, and Andrea Pezza. "Access of Individuals to the European Court of Justice of the European Union Under the New Text of Article 263, Para 4, TFEU." Rivista italiana di diritto pubblico communitario No. 5 (2014): 923948.

12. Méndez Pinedo, Elvira. "Access to Justice as Hope in the Dark: In Search for a New Concept in European Law." International Journal of Humanities and Social Science No. 1 (2011): 9-19. 
13. Micklitz, Hans. "Social Justice and Access Justice in Private Law." European University Institute Working Paper LAW No. 2011/02 (2011): 1-32 // http://ssrn.com/abstract=1824225.

14. Schütze, Robert. From Dual to Cooperative Federalism: The Changing Structure of European Law. Oxford: Oxford University Press, 2009.

15. Tuori, Kaarlo. European Constitutionalism. Cambridge: Cambridge University Press, 2015.

\section{LEGAL REFERENCES}

1. Alassini and Others. The Court of Justice of the European Union, 2010, Joined Cases C-317/08 to C-320/08.

2. Aziz Melki and Sélim Abdeli. The Court of Justice of the European Union, 2010, Joined Cases C-188/10 and C-189/10.

3. Beschluss der 3. Kammer des Zweiten Senats. Bundesverfassungsgericht. The Federal Constitutional Court of the Federal Republic of Germany, 2014, 2 BvR 1549/07.

4. Bosphorus Hava Yollari Turizm Ve Ticaret Anonim Sirketi v Ireland. The European Court of Human Rights, 2005, no. 45036/98.

5. Chalkor v. Commission. The Court of Justice of the European Union, 2011, C-386/10 P.

6. Charter of Fundamental Rights of the European Union. Official Journal of the European Union, 2010, OJ C83/02.

7. Comet $v$ Produktschap voor Siergewassen. The Court of Justice of the European Union, 1976, Case 45/76.

8. Consolidated version of the Treaty on the European Union. Official Journal of the European Union, 2008, OJ C115.

9. Consolidated version of the Treaty on the Functioning of the European Union. Official Journal of the European Union, 2008, OJ C115/01.

10. Council of the European Union and Others $v$ Vereniging Milieudefensie and Stichting Stop Luchtverontreiniging Utrecht. The Court of Justice of the European Union, 2015, Joined Cases C-401/12 P and C-403/12 P.

11. Deutsche Energiehandels- und Beratungsgesellschaft $\mathrm{mbH} v$ Bundesrepublik Deutschland. The Court of Justice of the European Union, 2010, C-279/09.

12. Dhahbi v Italy. The European Court of Human Rights, 2014, no. 17120/09.

13. Explanations relating to the Charter of Fundamental Rights. Official Journal of the European Union, 2007, OJ C303/02. 
14. Foto-Frost v Hauptzollamt Lübeck-Ost. The Court of Justice of the European Union, 1987, Case 314/85.

15. Global Starnet Ltd $v$ Ministero dell'Economia e delle Finanze and Amministrazione Autonoma Monopoli di Stato. The Court of Justice of the European Union, 2017, Case C-322/16.

16. Inuit Tapiriit Kanatami and Others $v$ European Commission. The Court of Justice of the European Union, 2015, C-398/13 P.

17. Inuit Tapiriit Kanatami and Others $v$ Parliament and Council. The Court of Justice of the European Union, 2013, C-583/11 P.

18. Inuit Tapiriit Kanatami and Others $v$ Parliament and Council. The Court of Justice of the European Union, 2011, Order in T-18/10.

19. Inuit Tapiriit Kanatami and Others $v$ Commission. The Court of Justice of the European Union, 2013, T-526/10.

20. Jégo-Quéré v Commission. The Court of Justice of the European Union, 2002, $\mathrm{T}-177 / 01$.

21. João Filipe Ferreira da Silva e Brito and Others v Estado Português. The Court of Justice of the European Union, 2015, C-160/14.

22. Juan Carlos Sánchez Morcillo and María del Carmen Abril García v Banco Bilbao Vizcaya Argentaria SA. The Court of Justice of the European Union, 2014, C$169 / 14$.

23. Lesoochranárske zoskupenie VLK $v$ Ministerstvo životného prostredia Slovenskej republiky. The Court of Justice of the European Union, 2011, C-240/09.

24. Marleasing SA v La Comercial Internacional de Alimentacion SA. The Court of Justice of the European Union, 1990, C-106/89.

25. NV Algemene Transporten Expeditie Onderneming van Gend en Loos $v$ Nederlandse Administratis der Belastingen. The Court of Justice of the European Union, 1963, Case 26/62.

26. Opinion 2/13, Accession of the European Union to the European Convention for the Protection of Human Rights and Fundamental Freedoms. The Court of Justice of the European Union, 2014.

27. Orizzonte Salute - Studio Infermieristico Associato v Azienda Pubblica di Servizi alla persona San Valentino - Città di Levico Terme and Others. The Court of Justice of the European Union, 2015, C-61/14.

28. Plaumann v Commission. The Court of Justice of the European Union, 1963, Case 25/62.

29. Rewe $v$ Landwirtschaftskammer fuer das Saarland. The Court of Justice of the European Union, 1976, Case 33/76. 
30. Schipani and Others v Italy. The European Court of Human Rights, 2015, no. 38369/09.

31. T \& L Sugars Ltd and Sidul Açúcares, Unipessoal Lda v European Commission. The Court of Justice of the European Union, 2013, T-279/11.

32. Telefónica SA v European Commission. The Court of Justice of the European Union, 2013, C-274/12 P.

33. Unibet (London) Ltd and Unibet (International) Ltd $v$ Justitiekanslern. The Court of Justice of the European Union, 2007, C-432/05.

34. Unión de Pequeños Agricultores $v$ Council. The Court of Justice of the European Union, 2002, C-50/00 P.

35. ZZ $\vee$ Secretary of State for the Home Department. The Court of Justice of the European Union, 2013, C-300/11. 